\title{
DAMAGE CAUSED BY BROWN-CAPUCHIN MONKEYS TO NINE PINUS SPECIES AND THE IMPLICATIONS FOR FOREST MANAGEMENT
}

\author{
Dieter Liebsch $^{1 *}$, Sandra Bos Mikich ${ }^{2}$ \\ ${ }^{1 *}$ Universidade Federal do Paraná, Setor de Ciências Agrárias, Departamento de Ciências Florestais. Curitiba, Paraná, Brazil - \\ liebschdieter@gmail.com \\ ${ }^{2}$ Embrapa Forestry, Ecology Laboratory, Colombo, Paraná, Brazil - sandra.mikich@embrapa.br \\ Recebido para publicação: 21/12/2015 - Aceito para publicação: 20/12/2016
}

\begin{abstract}
Damage caused by Sapajus nigritus to pine plantations is common in southern and southeastern Brazil. To assess the susceptibility to these primate attacks, the average percentage of trees with damage was calculated in continuous inventory plots of nine tropical and temperate Pinus spp. species, from four company plantations within the states of Parana and Santa Catarina. The results indicated a preference for P. taeda and P. greggii, with almost $97 \%$ of trees damaged. Regarding the least susceptible species, $P$. patula and $P$. palustris trees showed little $(0.01 \%)$ or no damage. The other Pinus species ranged from 1.4 to $11.8 \%$ damage. The preference of Brown-capuchin monkeys for P. taeda is particularly worrying, as it is the most widely planted species in southern Brazil. However, other species that suffer little or no damage could be used as an alternative plantation species that enable the diversification of crops and opens new perspectives for the improvement and genetic engineering of pine, which take into account the needs of different producers. It is recommended however, that these strategies are combined with the recovery of native forests, since damage to forest plantations is related to the low quality of the remaining surrounding native forest patches.

Keywords: Forest management; primate; Sapajus nigritus; Bark-stripping; Wildlife management.
\end{abstract}

\section{Resumo}

Danos causados por Sapajus nigritus a plantios de pínus são comuns no sul e sudeste do Brasil. Para avaliar a susceptibilidade ao ataque desses primatas, foi calculada a porcentagem média de árvores com danos em parcelas de inventário contínuo de nove espécies de Pinus spp. tropicais e temperado em plantios de quatro empresas nos estados do Paraná e Santa Catarina. Os resultados indicaram preferência por $P$. taeda e $P$ greggii, com cerca de $97 \%$ das árvores com danos. No que diz respeito às espécies menos susceptíveis, $P$. patula e $P$. palustris com poucas árvores com danos $(0.01 \%)$ ou não apresentaram danos. Outras espécies de Pinus variaram de 1.4 a $11.8 \%$ de árvores com danos. A preferência de macacos-prego por plantios de $P$. taeda é particularmente preocupante, já que é a espécie mais plantada no Sul do Brasil. No entanto, outras espécies que sofrem pouco ou nenhum dano, poderiam ser usadas como espécies alternativas, que possibilitem a diversificação de culturas e abre novas perspectivas para melhoria e engenharia genética do Pinus, de acordo com as necessidades dos diferentes produtores. Recomenda-se, no entanto, que essas estratégias sejam combinas com a recuperação de florestas nativas, uma vez que os danos estão associados a baixa qualidade dos fragmentos de florestas nativas no entorno dos plantios.

Palavras-chave: Manejo florestal; primata; Sapajus nigritus; descascamento; manejo de fauna.

\section{INTRODUCTION}

Brown-capuchin monkeys Sapajus nigritus (=Cebus [apella] nigritus) have an omnivorous diet consisting mainly of fruits, seeds, bulbs, insects, bird eggs and small vertebrates (JANSON; BOINKSI, 1992; WEHNCKE; DOMÍNGUEZ, 2007). They also show a large adaptability to anthropogenic forest ecosystems (CHIARELLO, 1999). Thus, this primate often occupies native forests associated with agricultural and forest plantations. Therefore, conflict emerges with producers on the basis of the damage that this primate causes to some crops, especially to Pinus species in southern Brazil (KOEHLER; FIRKOWSKI, 1996; ROCHA, 2000; SANTOS et al., 2007; MIKICH; LIEBSCH, 2014a).

Damage caused by Brown-capuchin monkeys to Pinus plantations are characterized by the removal of portions of bark from the upper third of the trunks of mature trees, in order to consume the phloem and sap, causing permanent damage (MIKICH; LIEBSCH, 2014a). Besides wood quality loss and reduction of the volumetric increase (LIEBSCH et al., 2015), the increased risk of attack by opportunistic pests such as the wasp timber (Syrex noctilio Fabricius (Hymenoptera, Siricidae)) and fungi can lead to the death of some damaged trees (FIRKOWSKI; KOEHLER, 1996). 
The first reports of damage to Pinus plantations in southern Brazil are from the 1950s (KOEHLER; FIRKOWSKI, 1996), but reports have increased in frequency in the last two decades, despite the low population density of Brown-capuchin monkeys found in regions where forest plantations are common (MIKICH; LIEBSCH, 2014a). Currently there are records of damage caused by Brown-capuchin monkeys to forest plantations in all three Southern Brazilian states, besides São Paulo State and Argentina (AGOSTINI et al., 2015). While most reports involve Pinus plantations, damage has also been observed in native or planted individuals of Araucaria angustifolia and in several Eucalyptus species (MIKICH; LIEBSCH, 2014a; LIEBSCH; MIKICH, 2015).

The forestry sector in Brazil accounts for 5.8\% of national GDP, and is especially important in the Southeast and South, where Eucalyptus and Pinus plantations are dominant (ABRAF, 2013). In South Brazil where this study was conducted, the forestry sector consists of more than 1.3 million hectares of Pinus, representing $87 \%$ of the plantations of this genus in the country, and 624,000 hectares of Eucalyptus (ABRAF, 2013). These forest stands were established 50-60 years ago and their supply chains have great social and economic importance (ABRAF, 2013). The distribution of Pinus plantations in Brazil is divided into two main areas, the temperate and the tropical climatic zones (AGUIAR et al., 2015). Among the species grown in the southern states, in temperate regions (Rio Grande do Sul, Santa Catarina and southern half of Paraná), Pinus taeda is the most common, followed by $P$. elliottii, both of which grown in large-scale commercial plantations; $P$. patula is grown only experimentally at present. In regions without the occurrence of frost, especially in the northern half of Paraná state and southern São Paulo state, there is also commercial scale planting of tropical species, such as P. caribaea, P. oocarpa, P. maximinoi and P. tecunumanii (AGUIAR et al., 2015). Among these species, preliminary assessments suggest that $P$. taeda is the species most frequently damaged by capuchin monkeys and that $P$. patula is avoided by this primate.

Although there might be a significant loss of timber production (LIEBSCH et al., 2015), the fact that the animal responsible for the damage is a native species and, therefore, protected by the Brazilian environmental legislation (Law no. 9.605, 12 February 1998), makes it necessary to search for management alternatives which could reduce such damage without compromising the survival of the monkeys or native forests that shelter this and other species. It is worth mentioning that there is already a recommendation (SANTOS et al., 2007) for the species to not be regarded as a pest, but rather as problem populations, since it does not cause damage to forest plantations in all areas where it resides. Furthermore, previous studies suggest that the presence of damage is related to the low availability of food in the native forests adjacent to plantations, since the sap is only consumed between August and December, when fruit production is low (MIKICH; LIEBSCH, 2014a). Although seasonal variation in fruit availability is primarily a natural phenomenon associated with climatic variables (MARQUES et al., 2004; LIEBSCH; MIKICH, 2009), degradation of native forests (area reduction, isolation and selective extraction of species) can further reduce the supply of fruit and increase the pressure on alternative resources, such as the sap of planted tree species (MIKICH; LIEBSCH, 2014a).

A series of measures to reduce the damage caused by $S$. nigritus to forest plantations have been proposed, such as relocation of groups, sterilization of males, creation of firebreaks and supplemental feeding (ROCK, 2000; MIKICH; LIEBSCH, 2014B). A critical review of these proposals, as well as the presentation of potential alternatives, such as the identification of Pinus species with lower frequencies of damage, was presented by Mikich and Liebsch (2014a). The results presented here are part of this strategy, developed in partnership with the commercial sector in order to reduce the economic losses caused by S. nigritus to forest plantations and minimize conflicts between production and conservation.

\section{MATERIALS AND METHODS}

Damage to nine species of Pinus was quantified for four tropical species ( $P$. caribaea, $P$. maximinoi, $P$. tecunumanii and P. oocarpa) and three temperate species (P. greggii, P. patula and P. palustris, ), as well as two species ( $P$. taeda and $P$. elliottii) with distribution in both climatic zones (AGUIAR et al., 2015). Field surveys were carried out in forest stands of four forestry companies, two in Paraná and two in Santa Catarina State. The selection of study areas took into account the presence of plantations with the following conditions: 1. Pinus taeda with recent damage (in the last three years), confirming the presence of problem populations of Sapajus nigritus in the area; 2. at least one other Pinus species with stands adjacent to that of $P$. taeda with damage, providing an alternative feeding species for S. nigritus; 3. Plantations greater than 6 years old, as damage is unusual in trees under this age (LIEBSCH et al., 2015).

The frequency of damage to the stands was recorded from April to June 2013 (after the annual period of damage) in plots systematically distributed, previously used for continuous forest inventories by the companies. Plots were circular, with their size ranging from 400 to $600 \mathrm{~m}^{2}$. Plots of the other stand species were set as close as possible to those of $P$. taeda (average distance $=383 \mathrm{~m}$, minimum $=28 \mathrm{~m}$ and maximum $=1.241 \mathrm{~m}$ ) and 
without apparent isolating barriers (e.g. roads), although previous data suggest that a group of Brown-capuchin monkeys can move up to $2 \mathrm{~km}$ /day, even crossing busy roads (unpublished data).

To evaluate damage among different species, we used the mean percentage of trees damaged in each plot. The mean damage per species for each company and the percentage of overall damage were compared (all species sampled). Differences in the mean of damaged individuals among species were compared by KruskalWallis and Mann-Whitney tests (ZAR, 1999).

\section{RESULTS AND DISCUSSION}

We evaluated 9,391 individuals from nine species of Pinus in 169 sample plots. The percentage of damaged trees showed significant differences among the nine species $(\mathrm{H}=138.5 \mathrm{p}<0.01)$. In general (Table 1$)$, the species were divided into three groups: 1 . High frequency of damage, with values close to $100 \%$, including $P$. greggii and P. taeda; 2. Mean frequency of damage with intermediate values, including $P$. oocarpa and $P$. tecunumanii; 3. Low frequency or no damage, including the rest of the species. When data were analyzed by sampling area (Table 2), the highest frequency of damage in P. taeda was evident in all comparisons. No damage was observed in P. palustris. In P. patula, even when the damage was present it was in much lower percentage $(0.01 \%)$ than in P. taeda $(74 \%)$.

Table 1. Mean percentage of individuals from different species of Pinus with damage caused by Browncapuchin monkeys (Sapajus nigritus) in 169 sample plots located in southern Brazil. Where: $\mathrm{n}=$ number of plots sampled for each species of Pinus; \% Damage = mean percentage of individuals with damage in total sampled plots for each species.

Tabela 1. Porcentagem media de indivíduos de diferentes espécies de Pinus com danos causados por macacosprego (Sapajus nigritus) em 169 parcelas localizadas no Sul do Brasil. Onde: $\mathrm{n}=$ número de parcelas amostradas para cada espécie de Pinus; \% Danos = porcentagem média dos indivíduos com danos no total das parcelas amostradas para cada espécie.

\begin{tabular}{lcc}
\hline Species & n & \% damage \\
\hline P. greggii & 8 & $96.8 \mathrm{a}$ \\
P. taeda & 72 & $80.3 \mathrm{a}$ \\
P. oocarpa & 10 & $11.8 \mathrm{ab}$ \\
P. tecunumanii & 6 & $4.5 \mathrm{ab}$ \\
P. elliottii & 14 & $2.4 \mathrm{~b}$ \\
P. caribaea & 15 & $1.9 \mathrm{~b}$ \\
P. maximinoi & 8 & $1.4 \mathrm{~b}$ \\
$P$. patula & 29 & $0.1 \mathrm{~b}$ \\
$P$. palustris & 7 & $0.0 \mathrm{~b}$ \\
\hline (1) Means followed by the same letter in the columns do not differ by Kruskal-Wallis test at \\
1\% probability.
\end{tabular}

Table 2. Frequency of damage to nine different Pinus species caused by Brown-capuchin monkeys in four sampling areas of southern Brazil. Where: $n=$ number of plots sampled for each species of pine in each company (area); \% Damage = average percentage of individuals with damage in total sampled plots for each species in each company.

Tabela 2. Frequência de danos em nove diferentes espécies de Pinus causados por macacos-prego (Sapajus nigritus) em quatro áreas do sul do Brasil. Onde: $\mathrm{n}=$ número de parcelas amostradas em cada empresa (área); para cada espécie de Pinus; \% Danos = porcentagem média de indivíduos com danos de cada espécie amostrados nas parcelas em cada empresa (área).

\begin{tabular}{lrr}
\hline Areas and Species & $\mathbf{N}$ & \% damage \\
\hline Area 1 & & $\mathrm{H}=36.2 \mathrm{p}<0.01^{(1)}$ \\
$P$. taeda & 17 & $85.6 \mathrm{a}$ \\
P. oocarpa & 10 & $14.8 \mathrm{ab}$ \\
P. tecunumanii & 6 & $4.5 \mathrm{~b}$ \\
P. caribaea & 15 & $4.0 \mathrm{~b}$ \\
P. maximinoi & 8 & $2.6 \mathrm{~b}$ \\
\hline Area 2 & & $\mathrm{H}=29.27 \mathrm{p}<0.01^{(1)}$ \\
$P$. taeda & 19 & $80.3 \mathrm{a}$ \\
P. palustris & 7 & $0.0 \mathrm{~b}$ \\
P. patula & 10 & $0.0 \mathrm{~b}$ \\
\hline
\end{tabular}

FLORESTA, Curitiba, PR, v. 47, n. 1, p. 37 - 42, jan. / mar. 2017.

Liebsch, D.; Mikich, S. B.

ISSN eletrônico 1982-4688

DOI: $10.5380 /$ rf.v47i1.44524 


\begin{tabular}{lcr}
\hline Area 3 & & $\mathrm{H}=47.61 \mathrm{p}<0.01^{(1)}$ \\
$P$. taeda & 28 & $73.8 \mathrm{a}$ \\
$P$. elliottii & 14 & $2.4 \mathrm{~b}$ \\
$P$. patula & 19 & $0.1 \mathrm{~b}$ \\
\hline Area 4 & & $\mathrm{U}=64 \mathrm{p}<0.05^{(2)}$ \\
$P$. taeda & 8 & $100.0 \mathrm{a}$ \\
$P$. greggii & 8 & $96.8 \mathrm{~b}$ \\
\hline (1) Means followed by the same letter in the columns do not differ by Kruskal-Wallis test at \\
1\% probability. \\
(2) Means followed by the same letter in the columns do not differ by Mann-Whitney \\
test at 5\% probability.
\end{tabular}

The results clearly demonstrate that Sapajus nigritus is selective regarding the sap of some species of Pinus, to the point of practically not consuming the sap of some species, even when they are as abundant and easily accessible as the preferred ones. On the one hand this is a concern, since $P$. taeda, the species most frequently damaged, is the most commonly planted species, with approximately 1.3 million hectares planted in southern Brazil (ABRAF, 2013; AGUIAR et al., 2015). On the other hand, however, this information demonstrates that other Pinus species are less susceptible to damage by this primate, which introduces the possibility for diversification of crops in order to reduce economic losses.

Among the species with low intensity of damage, $P$. patula should be highlighted as an alternative for locations with low temperatures, since it presents good growth (AGUIAR et al., 2015) and production faces fewer obstacles than $P$. palustris, which could also be suitable for temperate climates, as no damage was observed to the experimental plantings of this species. It is worth noting that, despite suffering damage, $P$. patula is also cited as a species that has been negatively selected by groups of baboons (Papio ursinus) in South Africa (FERGUSON, 2005). For tropical Pinus species, though all showed damage, the frequency of this has always been much lower than in $P$. taeda. Among tropical species, however, $P$. caribaea is the only widely planted species in Brazil's tropical region and parts of Paraná, covering an area of approximately 700,000 hectares (AGUIAR et al., 2015).

One of the main limiting factors to using several Pinus species is the long process involved in breeding Pinus in Brazil, which initially focused on species with greater economic value, among them $P$. taeda, $P$. caribaea and P. elliottii (AGUIAR et al., 2015). Large companies directed their breeding programs, supply chains and technological processes towards these species, making it difficult for further research on other species. However, it is important to remember that in addition to forest companies focused on pulp and wood, the timber production of many small and medium producers can also be affected by monkeys. The tendency is for these economic impacts to be greater for medium and small sized companies than for larger companies, due to the smaller scale of commercial plantations among other factors. This situation has often led to the slaughter of Brown-capuchin monkeys, which besides being an illegal practice, poses a threat to biodiversity and even to the sustainability of production, as this primate is an important disperser of forest seeds (WEHNCKE; DOMÍNGUEZ; 2007; MIKICH et al., 2015) and is potentially involved in the control of insect pests in forestry and agriculture (MIKICH et al., 2015).

Thus, it is recommended that further research be directed towards breeding programs with alternative Pinus species, diversifying crops and creating alternatives for small, medium and large producers focused on high timber productivity and low consumption by Brown-capuchin monkeys. Furthermore, attention should be given to the recovery of degraded forests (such as Legal Reserves and Permanent Preservation Areas) with fruit species eaten by capuchin monkeys, particularly those that produce fruit out of peak fruiting times to reduce feeding pressure on the Pinus sap. Minimizing this problem must involve not just research institutions and forestry companies, but various sectors of society in the search for better ways of reconciling production with conservation.

\section{CONCLUSION}

- $\quad$ Brown-capuchin monkeys do select positively (preferred) for the sap of some pine species (P. taeda and $P$. greggii) and negatively (avoided) for others (P. patula and P. palustris).

- Homogeneous plantations of preferred pine species should be discouraged in areas with high incidence of primate damage, especially among medium and small producers,

- Avoided pine species could be used directly as alternative crop species or as material for genetic and chemical (search for repellents) engineering. 
- Conservation and restoration programs focused on improving the quality of native forest remnants and the quantity of fruit available to capuchins during the austral winter should take place irrespective of other forest management technique applied.

\section{ACKNOWLEDGEMENTS}

This work is part of the PROGRAMA MACACO-PREGO (www.embrapa.br/florestas/programa-macacoprego) coordinated by Embrapa Forestry since 2003 in partnership with the planted forest sector. It was supported by EMBRAPA (Empresa Brasileira de Pesquisa Agropecuária), APRE (Associação Paranaense de Empresas de Base Florestal), and FUNCEMA (Fundo Nacional para o Controle de Pragas Florestais). The authors thank the companies Celulose Irani, Florestal Vale do Corisco, MWV Rigesa and Remasa Reflorestadora for allowing the data collection in their areas. CNPq (Conselho Nacional de Desenvolvimento Científico e Tecnológico) granted a $\mathrm{PhD}$ scholarship (141 346 / 2014-0) to DL and Elizabeth Raine kindly edited the English version.

\section{RERERENCES}

ASSOCIAÇÃO BRASILEIRA DE PRODUTORES DE FLORESTAS PLANTADAS (ABRAF). Anuário estatístico da ABRAF - ano base 2012. Brasília, 148 p. 2013.

AGostini, I.; PIZZIO, E.; DE ANGELO, C.; DI BITETTI, M. S. Population Status of Primates in the Atlantic Forest of Argentina. International Journal of Primatology, v. 36, p. 244-248, 2015.

AGUIAR, A. V.; SOUZA, V. A.; SHIMIZU, J. Y. Sistemas de Produção: cultivo do Pinus. 2. ed. Curitiba: Embrapa Florestas. Disponível em: <http://sistemasdeproducao.cnptia.embrapa.br/FontesHTML/Pinus/Cultivo doPinus_2ed/index.htm>. Acesso em: 03 março de 2015.

CHIARELLO, A. G. Effects of fragmentation of the Atlantic forest on mammal communities in south-eastern Brazil. Biological Conservation, v. 89, n. 1, p. 71-82, 1999.

FERGUSSON, R. A. Review of baboons, baboon damage and baboon control in South African plantation forests, with particular reference to Mpumalanga province. Editado por South African Baboon Damage Working Group. Zimbábue, 44 p, 2005.

JANSON, C. H.; BOINSKI, S. Morphological and behavioral adaptations for foraging in generalist primates: the case of the cebines. American Journal of Physical Anthropology, v. 88, p. 483-498, 1992.

KOEHLER, A.; FIRKOWSKI, C. Descascamento de pinus por Cebusapella. Floresta, v. 24. p. 61-75, 1996.

LIEBSCH, D.; MIKICH, S. B. Fenologia reprodutiva de espécies vegetais da Floresta Ombrófila Mista do Paraná, Brasil. Revista Brasileira de Botânica, v. 32, n. 2, p. 375-391, 2009.

LIEBSCH, D.; MIKICH, S. B. First record of Eucalyptus spp. bark-stripping by Brown-capuchin monkeys (Sapajus nigritus, Primates: Cebidae). Ciencia Florestal, v. 25, n. 2, p. 501-505, 2015.

LIEBSCH, D.; MIKICH, S. B.; OLIVEIRA, E. B.; MOREIRA, J. M. M. A. P. Descascamento de Pinus taeda por macacos-prego (Sapajus nigritus): tipos e intensidades de danos e seus impactos sobre o crescimento das árvores. Scientia Forestalis, v. 43, p. 37-49, 2015.

MARQUES, M. C. M.; ROPER, J. J.; SALVALAGGIO, P. B. Phenological patterns among plant life-forms in a subtropical forest is southern Brazil. Plant Ecology, v. 173, p. 203-213, 2004.

MIKICH, S. B.; LIEBSCH, D. Damage to forest plantations by tufted capuchins (Sapajus nigritus): too many monkeys or not enough fruits? Forest Ecology and Management, v. 314, p. 9-16, 2014a.

MIKICH, S. B.; LIEBSCH, D. Assessment of food supplementation and surveillance as techniques to reduce damage caused by black capuchin monkeys Sapajus nigritus to forest plantations. Current Zoology, v. 60, p. 581-590, 2014b.

MIKICH, S. B.; LIEBSCH, D.; ALMEIDA, A.; MIYAZAKI, R. D. O papel do macaco-prego Sapajus nigritus na dispersão de sementes e no controle potencial de insetos-praga em cultivos agrícolas e florestais. In: PARON, L. M.; GARCIA, J. R.; OLIVEIRA, E. B.; BROWN, G. G.; PRADO, R. B. (Eds). Serviços Ambientais em Sistemas Agrícolas e Florestais do Bioma Mata Atlântica. Brasília: Embrapa, 2015, p. 250-258.

ROCHA, V. J. Macaco-prego, como controlar esta nova praga florestal? Floresta, v. 30, p. 95-99, 2000.

FLORESTA, Curitiba, PR, v. 47, n. 1, p. 37 - 42, jan. / mar. 2017.

Liebsch, D.; Mikich, S. B.

ISSN eletrônico 1982-4688

DOI: $10.5380 /$ rf.v47i1.44524 
SANTOS, C.V.; MORAIS JR, M. M.; OLIVEIRA, M. M. DE; MIKICH, S. B.; RUIZ-MIRANDA, C. R.; E MOORE, K. P. L. Ecologia, comportamento e manejo de primatas invasores e populações-problema. In: BICCA-MARQUES, J. C. (Ed). A primatologia no Brasil, v. 10, Porto Alegre: Sociedade Brasileira de Primatologia, 2007, p. 101-118.

WEHNCKE, E. V.; DOMÍNGUEZ C. A. Seed dispersal ecology of non-restricted frugivores, capuchin monkeys in three neotropical forests. Journal of Tropical Ecology, v. 23, p. 519-528, 2007.

ZAR, J. H. Biostatistical analysis. Upper Saddle River, NJ: Prentice Hall, v. 1, p. 389-394, 1999. 